\title{
QUANDO O TRABALHADOR ASSALARIADO É CAMPONÊS: um estudo dos agricultores camponeses nos campos de dendê no nordeste paraense
}

\section{CUANDO EL TRABAJADOR ASALARIADO ES CAMPESINO: un estudio de los agricultores campesinos en los campos de dendê en el nordeste paraense, Brasil}

\author{
Rafael Benevides de Sousa \\ Doutor em Geografia \\ Professor da Universidade Federal do Sul e Sudeste do Pará, Instituto de Estudos do Trópico Úmido, \\ Xinguara, PA, Brasil \\ benevidessousa@gmail.com
}

\begin{abstract}
Resumo
Compreender as articulações que o campesinato tem engendrado junto às formas capitalistas de produção tem sido um campo de estudo e pesquisa importante para o entendimento das relações que estão sendo tecidas no espaço agrário. Nesse sentido, nos propomos nesse artigo a discutir as relações que são constituídas por camponeses que se assalariam nas empresas produtoras de dendê no nordeste paraense, concebendo esse assalariamento como um complemento para o fortalecimento da unidade familiar camponesa. As reflexões que aqui trazemos partiram de uma pesquisa em comunidades rurais nos municípios de Acará, Bujaru e Concórdia do Pará, onde estão situadas algumas das bases de produção da empresa Biopalma. A metodologia de análise geográfica ocorreu por intermédio da pesquisa de campo, a partir de técnicas da observação in loco e de entrevistas com camponeses. Nesse artigo, mais especificamente, privilegiamos a base de dados qualitativos, por entendermos a importância que as falas dos entrevistados imprimem à compreensão da realidade agrária apresentada. Desse modo, esperamos poder contribuir com o debate sobre as relações construídas dialeticamente entre camponeses e o binômio latifúndio/agronegócio na Amazônia paraense.
\end{abstract}

Palavras-chave: Camponeses. Trabalho assalariado. Dendê. Nordeste paraense.

\section{Resumen}

Comprender las articulaciones que el campesino ha establecido con las formas capitalistas de producción ha sido un campo de estudio e investigación importante para el entendimiento de las relaciones que se tejen en el espacio agrario. En este artículo nos proponemos discutir las relaciones que son constituidas por campesinos que realizan trabajos asalariados en las empresas productoras de dendê en el nordeste paraense brasilero, concibiendo esa relación salarial como un complemento para el fortalecimiento de la unidad familiar campesina. Las reflexiones que aquí traemos partieron de una investigación en comunidades rurales en los municipios de Acará, Bujaru y Concórdia do Pará, donde están situadas algunas de las bases de producción de la empresa Biopalma. Las reflexiones presentadas son el fruto del trabajo de campo, a partir de técnicas da observación in locus y de entrevistas con campesinos. Privilegiamos los datos 
cualitativos, pues entendemos la importancia que los testimonios de los entrevistados imprimen a la comprensión de la realidad agraria presentada. De esta manera esperamos poder contribuir con el debate sobre las relaciones construidas dialécticamente entre campesinos y el binomio latifundio/agronegocio en la Amazonia paraense.

Palavra-llave: Campesinos. Trabajo assalariado. Dendê. Nordeste paraense.

\section{Introdução}

O desenvolvimento do binômio latifúndio/agronegócio e de outras formas de exploração/produção capitalistas no espaço agrário coloca em questão o papel que o campesinato - entre outras populações agrárias e extrativistas - pode desempenhar frente a outras racionalidades de trabalho promovidas para a reprodução ampliada de capital.

Com o advento das formas de produção capitalista, o lugar do campesinato dentro desse sistema econômico e de sociedade sempre foi concebido como sendo um modo de vida e de trabalho incompatível com as relações de produção e reprodução de capital, contribuindo para a diluição do campesinato dentro da classe operária nas cidades e no campo, e uma diferenciação social entre agricultores ricos e pobres (KAUTSKY, 1986; LENNIN, 1985). Contudo, compreendemos que dentro do sistema capitalista possam existir relações não capitalistas, coexistindo dialeticamente, reproduzindo-se mutualmente no espaço agrário (LUXEMBURGO, 1979; MARTINS, 1996; OLIVEIRA, 1991).

Desse modo, propõe-se discutir nesse artigo as relações de trabalho que são articuladas entre os camponeses (entendendo estes como não capitalistas, por desempenharem o trabalho familiar e não o assalariado nas suas unidades de produção) e as empresas do agronegócio do dendê, compreendendo o assalariamento nos campos da oleaginosa, longe de uma descampesinização ou proletarização, como um processo que permite o fortalecimento da unidade camponesa, realizando-se como uma estratégia a mais de sobrevivência do núcleo familiar no campo.

Em termos metodológicos, temos a compreensão de que essa contradição que se abre entre a família camponesa e o camponês que se assalaria (temporariamente ou permanentemente) se faz por entendermos só ser possível uma proletarização do campesinato quando este se encontrar totalmente separado dos seus meios de sobrevivência e produção, ou seja, somente quando a família concebe os meios de 
sobrevivência apenas pelo salário e não mais oriundo das relações familiares que giram dentro da unidade doméstica.

Como será possível observar nas falas transcritas dos camponeses com quem tivemos contato, a dualidade entre o trato com a roça familiar e o assalariamento tem permitido a permanência dessas famílias no campo, possibilitando a reprodução social por meio de outras estratégias de aquisição de renda para família que não somente da roça. Nesse caso, o assalariamento torna-se uma maneira de a família manter as bases produtivas da unidade doméstica, proporcionando, portanto, mais um elemento na receita familiar, do que uma proletarização total desses camponeses.

Diante dessa perspectiva, buscamos como objetivo nesse artigo compreender as ações de assalariamento de camponeses nos campos de dendê do pólo de produção da empresa Biopalma, abrangendo os municípios de Acará, Bujaru e Concórdia do Pará, todos no nordeste paraense. $\mathrm{O}$ caminhar da pesquisa se deu em sete comunidades rurais: Mariquita em Acará; Conceição do Guajará e São João Batista em Bujaru; e Arapiranga, Nova Esperança, Castanhalzinho e Nossa Senhora do Perpétuo Socorro em Concórdia do Pará. Essas comunidades foram escolhidas por estarem situadas no epicentro das plantações de dendê da empresa, confluindo para uma disputa territorial entre o agronegócio e a agricultura camponesa nesses municípios.

Como será visto mais à frente, com a expansão desse agronegócio nessa região, houve a busca pelo trabalho assalariado pelas famílias camponesas dessas comunidades que, há décadas, tinham no trabalho com a roça o principal meio de sustento familiar.

O percurso metodológico da pesquisa desenvolveu-se por meio de técnicas quantitativas e qualitativas de análise espacial, contudo, para este trabalho escolhemos trazer a abordagem qualitativa, realizando nossas análises a partir da oralidade dos camponeses entrevistados em campo ${ }^{1}$.

Como o leitor observará, privilegiamos as falas dos camponeses por entendermos que as situações aqui tratadas podem ser melhor entendidas a partir do relato oral desses sujeitos sociais, que se encontram à margem dos projetos de desenvolvimento impostos ao espaço agrário paraense.

Desse modo, visamos contribuir com as discussões acerca das relações geradas entre o binômio latifúndio/agronegócio com as populações camponesas, entendendo o 
movimento do assalariamento camponês como uma estratégia de fortalecimento da unidade familiar camponesa.

\section{Do chão da roça ao chão do dendê: formas laborais de agricultores camponeses}

As relações de trabalho familiar reproduzidas no seio das comunidades camponesas têm sido fadadas à extinção diante da expansão da agricultura capitalista que, especializam-se com trabalho o no campo, criando um imaginário da proletarização do campesinato via homogeneização do trabalho assalariado e das formas de produção capitalistas. Tal perspectiva, enunciada desde os estudos clássicos da questão agrária, tem sido destinada às famílias camponesas que se encontram nos interstícios do agronegócio do dendê, tal qual evidenciado nos trabalhos de Monteiro (2014) e Nahum e Bastos (2017).

Seguindo uma perspectiva metodológica de pesquisa e análise espacial a partir da unidade doméstica camponesa, ou seja, do chão da roça, concebemos que o assalariamento no chão do agronegócio do dendê tem sido um complemento à renda gerada pelos agricultores camponeses locais, estruturando uma combinação entre antigas e novas relações de trabalho que incidem sobre a resistência e a permanência desses agricultores camponeses no campo, mantendo a continuidade na posse dos meios de trabalho e de vida.

A partir de Ianni (1979), apresentamos uma compreensão metodológica que o suposto processo de proletarização ou descampesinização, via dendê, só é possível após a separação total do campesinato dos seus meios de produção. Nesse sentido, a nossa pesquisa e a tese aqui defendida estão alicerçadas na perspectiva de que as rendas providas do processo de assalariamento possibilitam a manutenção e o fortalecimento das unidades camponesas que ressignificam seus territórios a partir de outros elementos, o que antes era exclusivamente reproduzido por meio da roça. Desse modo, entendemos que as fissuras do agronegócio do dendê têm gerado mais um processo de campesinização do que de descampesinização.

Essa campesinização a partir do trabalho assalariado é aqui entendido no âmbito do trabalho remunerado que membros da família camponesa realizam fora da propriedade, como o que acontece nas empresas produtoras do dendê. A campesinização, nesse caso especifico, ocorreria pelo fortalecimento da unidade familiar, proporcionando 
a territorialização permanente desses camponeses na terra de trabalho (MARTINS, 1980), mesmo que assalariados. Desse modo, o salário recebido com essa forma de trabalho é reinvestido para a manutenção da unidade doméstica, como um reforço na renda familiar provida da agricultura. Tal processo pode ser visto na fala a seguir:

\begin{abstract}
A gente continua com a roça porque é necessário. A roça a gente faz mais pro consumo, a gente não vende mais. Agora, eu tô trabalhando com meu sogro e minha sogra, a gente faz junto. Depois que ele começou a trabalhar lá, mudou um pouco, ficou mais melhor, entrou mais dinheiro, a gente conseguiu fazer essa casa, que a gente morava numa casa velha, velha quase caindo. Aí conseguimos construir essa casa. Mas também o que ele ganha não é muita coisa. Ou continua com a roça ou passa fome. Por isso que a gente ainda tem roça, o arroz, feijão pro consumo, o milho é pras galinha, a gente não vende o milho. Faz farinha, tudo só pro consumo. (L. A., comunidade Nova Esperança, Concórdia do Pará, 20 de agosto de 2017).
\end{abstract}

O depoimento de L. A. demonstra a importância da roça na receita doméstica, mesmo o cônjuge trabalhando como assalariado nos campos de dendê, não sendo possível viver somente do salário alcançado com este trabalho. Desse modo, partimos da compreensão de que para esta família camponesa, a troca do trabalho pelo salário pode ser uma estratégia para a manutenção do sítio e para a conquista de bens, antes difíceis de serem contraídos exclusivamente do trato com a agricultura de roça. Por outro lado, a permanência com o trabalho na roça continua sendo um esteio importante para a família, principalmente pelo reconhecimento de que a renda do trabalho assalariado não é suficiente para o bem-estar da família. Tal relação entre o trabalho familiar e assalariado é vislumbrada na tabela 01 :

Tabela 01: Relação entre trabalho familiar e trabalho assalariado

\begin{tabular}{lccccc}
\hline \multicolumn{1}{c}{ Comunidades } & $\begin{array}{c}\text { Trabalho } \\
\text { familiar }\end{array}$ & $\begin{array}{c}\text { Trabalho } \\
\text { assalariado }\end{array}$ & $\begin{array}{c}\text { Trabalho } \\
\text { familiar e } \\
\text { assalariado }\end{array}$ & $\begin{array}{c}\text { Unidades } \\
\text { familiares } \\
\text { pesquisadas }\end{array}$ & $\begin{array}{c}\text { Número de } \\
\text { famílias por } \\
\text { comunidades }^{3}\end{array}$ \\
\hline Arapiranga & 15 & 10 & 8 & 20 & 41 \\
Castanhalzinho & 16 & 3 & 3 & 17 & 25 \\
Conceição do Guajará & 12 & 1 & 1 & 12 & 12 \\
São João Batista & 17 & 5 & 3 & 25 & 80 \\
N. Sra. do Perpétuo Socorro & 21 & 12 & 9 & 25 & 150 \\
Mariquita & 18 & 4 & 3 & 24 & 24 \\
Nova Esperança & 16 & 10 & 4 & 20 & 25 \\
\hline
\end{tabular}

Fonte: Pesquisa de campo / Organização: Rafael B. de Sousa.

A tabela 01 destaca a relação entre o trabalho familiar camponês e o trabalho assalariado na Biopalma entre as unidades domésticas pesquisadas. Observamos que as comunidades de Arapiranga, Nossa Senhora do Perpétuo Socorro e Nova Esperança são 
as que possuem maior número de trabalhadores assalariados. Contudo, o trabalho familiar ainda é predominante em todas as comunidades, o que sinaliza o assalariamento como um complemento para a renda familiar que, ainda tem no sistema de roça o esteio de sustento e reprodução social.

As comunidades de Conceição do Guajará e Mariquita, no qual conseguimos abranger o número total de famílias, são as que possuem menor número de assalariados, o que demonstra a predominância do trabalho familiar camponês nesses territórios em disputa.

O assalariamento nesse contexto do dendê é visto pelas famílias camponesas como uma oportunidade de conseguir bens duráveis (casa, motocicleta, utensílios de trabalho e eletrodomésticos) que possibilitem maior conforto na casa; e renda para investir na unidade doméstica em constante produção. Assim, não há de fato uma proletarização, mas uma reorganização da família camponesa engendrada em seus territórios, a fim de conservar e recriar seus afetos no campo, seja com a terra, seja com a família extensa, seja com a comunidade.

Meu filho segundo trabalhou nove meses na Biopalma. Aí, depois ele saiu que ele naquele tempo que entrou, esse trabalho aí era praticamente um trabalho escravo. $\mathrm{O}$ trabalhador pegava chuva no trabalho, relampeava não tinha o direito de sair. Aí quando foi um dia, ele tava trabalhando nove meses, aí deu uma chuva forte, período de fevereiro, aí deu um relâmpago, ele tava com o foice na mão, aí ele correu e se escondeu né, com medo do relâmpago. Aí o fiscal veio e disse que não, que ele tinha que trabalhar. Aí ele disse que não ia mais trabalhar pra esses caras. Trabalhou nove meses só e saiu. Ele entrou pra trabalhar porque vieram chamar ele, mas o roçado todo tempo ele teve, ele fazia a roça dele. Aí ele não tinha tempo de desmanchar, a gente desmanchava. Aí quando ele saiu, já tinha roçado, já tinha 3 tarefa de roça, ele nem esquentou a cabeça. Aí, esse dinheiro que ele adquiriu lá, ele comprou uma moto que era o sonho dele né. Aí, hoje ele não quis mais roça, ele trabalha com pimenta (M. G., comunidade Conceição do Guajará, Bujaru, 17 de maio de 2016).

Por esse depoimento, podemos observar que a sujeição do trabalho ao capital dificulta a permanência do camponês nos canteiros do dendê. A opção pelo assalariamento gera conflito entre as temporalidades da natureza e do tempo cronológico do relógio, este último demarcado pela empresa e pelas cotas produtivas a serem alcançadas ao longo do dia/mês. A permanência com o trabalho na roça configura-se, justamente, pelo reconhecimento de que o trabalho na empresa é temporário e instável, e manter as tarefas de roças no sítio da família é ter segurança de renda após a saída da empresa. 
Bombardi (2004, p. 58), ao estudar os camponeses do Bairro de Reforma Agrária, no estado de São Paulo, relata que "os camponeses têm algo que foi roubado dos trabalhadores assalariados: o tempo e a autonomia sobre o trabalho." A autonomia sobre o trabalho e o tempo são algumas das principais características da resistência camponesa, e o que movimenta o território na construção ou na manutenção dos elementos essenciais para a reprodução social na contramão da exploração capitalista, ocasionando uma adaptabilidade do modo de vida do campesinato na contemporaneidade, para o qual o assalariamento, contraditoriamente, torna-se um dos elementos que compete para a territorialização camponesa.

Quando afirmamos que os camponeses são livres, pois determinam seu trabalho e a intensidade do mesmo e são, portanto, donos de seu tempo, estamos afirmando, na [da] mesma maneira, que também eles são donos de seu território, na medida que constroem uma unidade territorial que se diferencia daquela na qual as relações de trabalho se dão de forma tipicamente capitalista. Os camponeses são "donos/senhores" de suas unidades territoriais uma vez que têm a liberdade de produzirem-nas/construírem-nas, ou seja, eles são donos não apenas de seu tempo, como também de seu "espaço", já que o transformam através do trabalho, não qualquer trabalho, mas do trabalho familiar (BOMBARDI, 2004, p. 59).

O trabalho familiar, característico da unidade camponesa, é o alicerce que possibilita uma atividade não capitalista inserida dialeticamente na sociedade capitalista. Essa contradição só é possível em razão da economia e do modo de vida camponesa ser realizado a partir das necessidades imediatas da família, diferente das unidades de produção capitalista que engendra mecanismos para a reprodução e a ampliação de capital, por meio da exploração do trabalho.

Podemos auferir, assim, que na unidade camponesa a assimetria do trabalho concentra-se na força de trabalho de cada membro familiar, numa divisão básica, mas não restrita; na hierarquia do saber-fazer, do gênero e da idade. Já na unidade capitalista a assimetria é vista por meio da exploração do trabalhador, da separação entre a força de trabalho e o fruto produzido por esse trabalho, pelo qual o capital amplia-se nas bases da mais-valia.

No capitalismo,

O trabalho produz a si mesmo e ao trabalhador como uma mercadoria. A vida que ele deu ao objeto volta-se contra ele como uma força estranha e hostil. Ele não se realiza em seu trabalho, mas nega-se a si mesmo. $\mathrm{O}$ objeto produzido pelo trabalho que se lhe opõe como um ser estranho, como uma força independente do produtor. O que constitui a alienação do trabalho? Primeiramente, ser o trabalho externo ao trabalhador, não fazer [fizer] parte de sua natureza, portanto, não se realizar. Seu trabalho é imposto, não há 
satisfação. O produto do seu trabalho não lhe pertence, mas pertence a outro. O trabalhador é despojado das coisas mais essenciais não só da vida, mas também do trabalho. O próprio trabalho transforma-se em um objeto que ele só pode adquirir com grande esforço. A apropriação do objeto aparece como alienação a tal ponto que, quanto mais objeto o trabalhador produz, tanto menos pode possuir e tanto mais fica dominado pelo seu produto, o capital (CONCEIÇÃO, 2017, p. 18-19).

Compreendemos o trabalho assalariado nos canteiros do dendê dentro desta perspectiva enunciada por Conceição (2017), visto que remete à alienação do trabalho como resultado do não reconhecimento do objeto produzido como parte da natureza de quem o produz. "Assim, o trabalhador, na medida em que não se reconhece nos frutos do seu trabalho, torna-se alienado. Cabe à ideologia do capital manter o processo de alienação; motor de todo processo de acumulação" (CONCEIÇÃO, 2017, p. 19).

Contudo, para o camponês, esse processo de alienação não se completa, por diversas razões: pelo trabalho assalariado nos campos de dendê ocupar apenas parte da sua vida; por momentos específicos de dificuldades; ou por caracterizar a conquista ou aquisição de um objeto que demandará mais trabalho, inclusive o assalariamento. Desse modo, entendemos que "o trabalho na terra implica na recusa e negação do trabalho alienado, pressuposto da sociedade capitalistas. É a negação da falta de liberdade, do controle do tempo e da dominação opressiva do trabalho" (SIMONETTI, 1999, p. 130).

Nesse contexto, "no imaginário camponês são reproduzidas as estruturas significativas que dão sentido à vida cotidiana: o eixo da vida está baseado na família, no trabalho familiar, e é justamente aí que está a especificidade do campesinato" (BOMBARDI, 2004, p. 57). Desse modo, o camponês pode se assalariar nos campos do dendê, mas, ao manter a unidade familiar em constante produção, possibilita a sua continuidade como tal a partir da persistência e da teimosia em conservar os meios de produção e a reprodução social por meio do trabalho familiar. Nesse caso, o campesinato tem que ser visto metodologicamente a partir da unidade familiar e não do camponês que isoladamente se assalaria.

O assalariamento nos canteiros da palma de óleo surge como estratégia ou criatividade da família em gerar renda complementar que assegure o bem-estar social dos integrantes da unidade doméstica, mediante às novas necessidades que surgem no decorrer da vida no campo. Nesse caso, o assalariamento torna-se uma ação da campesinização no espaço agrário, à medida que mantém a unidade familiar em 
funcionamento, ressignificando o território de vida a partir de outras rendas e não mais exclusivamente da roça.

Vergés (2011, p. 9), ao pensar “os novos camponeses” no México, expõe que o trabalho assalariado camponês não pode ser interpretado fora das redes de relações socioeconômicas das quais faz parte. Para o autor, a peculiaridade da agricultura mexicana estaria na não separação dos produtores diretos dos seus meios de produção, mesmo havendo o assalariamento - viés para a exploração camponesa pelo mecanismo das trocas desiguais na sociedade capitalista. Tal peculiaridade assemelha-se ao que é visto nas comunidades em estudo, nas quais o assalariamento pela oleaginosa não tem separado o camponês dos seus meios de produção.

Nesse caso, "a exploração assalariada de uma parte da força de trabalho rural é um aspecto da exploração da totalidade do trabalho camponês" (VERGÉS, 2011, p. 9). Assim, a reprodução das relações que giram em torno do trabalho assalariado no campo não pode ser interpretada isoladamente, mas tem que ser analisada levando em consideração o envolvimento que é reproduzido a partir da economia camponesa (VERGÉS, 2011).

\begin{abstract}
Vista em seu conjunto, a economia camponesa vende produtos, mas para garantir sua reprodução sente-se obrigada também a vender o excedente da força de trabalho que não pode absorver. Em todos esses intercâmbios, o campesinato se vê submetido a uma transferência de valor. Ao englobar a venda da mão de obra dentro dos intercâmbios assimétricos praticados pelo camponês, torna-se evidente que não apenas a produção mercantil camponesa transfere seu excedente, mas também que uma importância igual à da maisvalia contida na produção para autoconsumo aparece no ciclo do capital quando este incorpora a força de trabalho parcialmente autossustentável (VERGÉS, 2011, p. 9).
\end{abstract}

Observamos nesse contexto que o capital apropria-se tanto da renda quanto do trabalho camponês que, contraditoriamente, recriam-se pela apropriação das sutilezas do capital. Desse modo, entendemos que o assalariamento reproduzido a partir dos canteiros do dendê consome o trabalho excedente da unidade familiar camponesa, que aqui estamos chamando de trabalho assalariado - trabalho acessório.

Oliveira (1991) em diálogo teórico com Santos (1984), analisa o trabalho acessório como um componente importante na unidade camponesa por onde o trabalho assalariado também pode ocorrer.

A presença do trabalho acessório do camponês é outro elemento componente da produção camponesa. Através do trabalho acessório o camponês se transforma periodicamente em trabalhador assalariado, recebendo salário por período de trabalho. Essa transformação periódica constitui-se em fonte de 
renda monetária que suplemente o rendimento com as culturas em suas propriedades (OLIVEIRA, 1991, p. 57)

Essa perspectiva de Oliveira (1991) evidenciou-se na pesquisa quando observamos os camponeses que se assalariam nos campos de dendê da Biopalma, engendrando, por meio do rendimento salarial, um componente a mais na renda originada da produção do sítio familiar camponês.

O trabalho assalariado na Biopalma gerado pelos territórios das comunidades estudadas, demonstra uma nova organização social nos núcleos familiares, na qual um ou mais integrante divide-se entre a roça e o trabalho assalariado.

Eu já trabalhei na Biopalma, trabalhei seis anos de carteira assinada. Lá não era muito bom não, era trabalho do campo, muito pesado. Eu saí porque me tiraram, em 2015 eles demitiram muita gente e eu fui no meio também. Lá eu trabalhava cortando dendê, era plantando, esse serviço assim, é roçando. Era serviço braçal mesmo, entendeu. Mas quando eu trabalhava lá, eu nunca deixei de ter a minha roça, porque a roça é bom o cara ter na colônia, pra fazer um farinha de boa pra vender. Porque o cara ganha o salário, mas quase não serve pra nada. Eu acho o trabalho na roça menos penoso porque no dia em que o cara não quiser ir, ele não vai. E lá não, o cara tem que ir todo dia. Só não dia de domingo, só de segunda a sexta e sábado (S. P., comunidade Mariquita, Acará, 05 de setembro de 2016).

Na roça você vai trabalhar pra você, você vai tá lá até a hora que você quiser. Se você não quiser você não vai. E você vai pra lá [Biopalma], você vai ser mandado pelo outros e ainda vai trabalhar no serviço mais pesado. Porque lá o fiscal tá no seu pé, olha ninguém pode sentar, até pra molar a ferramenta você desamolou, você tem outro aqui pra mola pra você não parar. Cada turno tem um fiscal aqui em cima de você. (M. R., comunidade Castanhalzinho, Concórdia do Pará, 28 de janeiro de 2017).

A diferença entre a roça e o assalariamento é evidenciada nesses depoimentos, nos quais percebemos a autonomia do trabalho ser apresentada como um elemento importante na vida camponesa. No deslocamento para os campos do dendê, o trabalho é personificado pela lógica da produtividade, perdendo autonomia sobre a força de trabalho e sobre o significado do que está sendo produzido. No trabalho da roça, o camponês vende o que ele mesmo produz, em contrapartida, nos canteiros do dendê, ele vende apenas a sua força de trabalho. O produto é da empresa e é ela quem comercializa a produção.

Aqui, trabalhando na roça tem uma vantagem, a gente vai de manhã e vai até 11 hora, 11 e meia tá voltando. Aí, se a gente quiser voltar de meio dia pra tarde a gente volta, se não quiser a pessoa não volta, porque a pessoa não é mandado. A pessoa trabalha por conta própria. E na Biovale [Biopalma] não, tem uma diferença que a pessoa é mandada. Ele tem horário pra entrar e hora pra sair, né. Toda quatro hora da madrugada ele se levanta, ele saia pra pega o ônibus lá na rua. Mas por outra parte, como se diz, se tornava melhor que na roça, que tudo mês ele tinha o dinheiro dele. O salário dele, tinha vale compra, tinha plano de saúde, tinha tudo. Se adoecesse, era tudo por conta da firma. E 
a gente no roçado não, se a gente adoece, se a pessoa não tiver um dinheirozinho, aí a pessoa fica mais difícil, é arriscado morre (J. V., comunidade Castanhalzinho, Concórdia do Pará, 28 de janeiro de 2017).

A fala de J. V. complementa as falas anteriores, contudo demonstra uma concepção positiva em relação à garantia dos direitos trabalhistas do trabalho assalariado, principalmente nos momentos de dificuldades, como no caso de doença. Por outro lado, reconhece a autonomia sobre o tempo e a liberdade nas relações de trabalho, que nos campos do dendê são regulamentadas pela produtividade e pelo tempo cronológico do relógio.

A pesquisa tem sinalizado que os camponeses que se assalariam, na sua maioria, não deixam de confeccionar a roça, tal relação caracteriza-se pela segurança alimentar que esse trabalho oferece em relação à vulnerabilidade do trabalho assalariado. Com isso, ocorre uma organização interna por toda extensão familiar que, em diferentes situações, o trabalho em conjunto se faz necessário a fim de manter as tarefas de roça em atividade.

O meu filho e minha filha trabalham na Vale. Eles tão pra lá agora. Mas quando eles tão com a hora vaga, eles vão pros servicinho deles, eles vão pra roça também. Porque aqui é o seguinte, a pessoa que trabalha empregado, é bom, mas na hora que sai, eles tem que ter um encosto né. Porque tem gente que só quer emprego, mas na hora que não tá trabalhando lá, procura outro serviço aqui né (F. S., comunidade Mariquita, Acará, 10 de setembro de 2016).

É o seguinte, o emprego acaba, depois que acabou o emprego não tem mais com que o cara se confiar. E como assim eles estão fazendo, trabalhando e não desistindo do daqui, quando eles sair um dia de lá, eles já tem do que viver aqui que é a roça. É por isso também que comprei esse terreno, é uma segurança, o que eles fazem aqui dentro é deles (J. G., comunidade Nova Esperança, Concórdia do Pará, 20 de agosto de 2017).

Eu tenho um filho que é técnico agrônomo, aí ele foi pra lá pra Biovale. Ficou um ano e oito meses. Aí eu vi que era muito sofrimento pra ele. Aí chamei ele, conversei com meu marido. Tu não acha que é muito sofrimento, porque invés de tu tá trabalhando pros outros, bora trabalhar pra cá que tudo que a gente planta é nosso. Aí ele disse já que é assim, ele voltou a trabalhar com a gente, a gente vai se ajudando (P. C., comunidade Nossa Senhora do Perpétuo Socorro, Concórdia do Pará, 14 de maio de 2017).

Nesses depoimentos fica evidente a importância em garantir e manter a produção da unidade familiar mesmo após o assalariamento. $\mathrm{O}$ trabalho assalariado, nesse caso, não é concebido como um meio de sobrevivência duradouro, mas como um período no qual determinados membros da família têm para adquirir outra renda ou mesmo experiência, além do trabalho com a roça.

Observamos nas falas dos entrevistados as diferentes formas interpretativas dos pais sobre o trabalho assalariado dos filhos, uns, apesar de conceberem esse tipo de 
atividade como algo positivo, afirmam que o retorno para o trabalho no sítio é algo inevitável no futuro (próximo ou não). Por outro lado, notamos os pais que são totalmente contrários ao assalariamento, justamente por reconhecerem que a produção oriunda do trabalho familiar, dentro da própria unidade doméstica, pertence a própria família, ressaltando a autonomia camponesa.

Todos os assalariado, a maioria, eles trabalham na agricultura também. Trabalham aí dentro, trabalhar lá na empresa já é um dinheiro a mais um pouco, lá na empresa. Então, quase todos os funcionários têm seu próprio produto pra vender. Tem uns que plantam a mandioca, o arroz, feijão, milho né. Tem outros que pagam pra fazer o serviço, mas sempre tem roça. Eu mesmo tenho roça, eu faço duas tarefas no ano. Planto mandioca e milho. Arroz e feijão não plantei esse ano. Na empresa eu trabalho no campo, vendo se o fiscal não tão massacrando o funcionário, se o funcionário não tá trabalhando com o IPI irregular né. Porque bota furada, peneira furada, essas coisas é irregular. E vários tipos de coisas. Logo no começo teve muitos problemas, mas agora melhorou que o Ministério do Trabalho veio aí no Sindicato e melhorou bastante. $\mathrm{O}$ gerente que tinha aí, antes, ele era muito rígido, mas agora ele saiu por conta disso que ele saiu, porque não tava fazendo as coisas certas, era muita reclamação. Chegou até a notícia de papar a empresa né. O Ministério do Trabalho e o Sindicato paralisar aí né, porque estavam massacrando os funcionários (C. A., comunidade Arapiranga, Concórdia do Pará, 18 de julho de 2017).

Nesse depoimento, C. A. reforça a coexistência do trabalho de assalariado na Biopalma junto ao da roça pelos trabalhadores camponeses que têm se deslocado para os canteiros da palma.

Entendemos, a partir da pesquisa, que apesar de o trabalho assalariado conformar-se como um elemento importante para a receita econômica familiar camponesa, essa modalidade de trabalho não se desenvolve de forma permanente, gerando idas e vindas do assalariamento. Com isso, o retorno às atividades nas agriculturas permanentes e temporárias na propriedade camponesa possui um movimento constante.

Eu trabalhei um mês, falo um mês porque a partir que a pessoa começa a fazer os exames, a entrevista já vai contando né. Mas não deu certo, porque era pra ajuntar caroço né. Aí na época era muito feio o lado da planta, aí tinha muita cobra, aí eu tinha medo. Também teve a questão do horário que não me acostumei, aí eu peguei e sai. Agora eu prefiro mil vezes a roça, porque na roça, você vai a hora que quer e volta a hora que quer. E lá não, você vai, tem que cumprir o horário. Era um horror ter que sair 3 horas de manhã todo dia (J. C., comunidade Nova Esperança, Concórdia do Pará, 21 de agosto de 2017).

Nessa fala, observamos que J. C. não se acostumou com o trabalho assalariado, perdendo não apenas a autonomia sobre o seu trabalho, mas também sobre o seu tempo, 
estipulado de forma diferente entre a agricultura capitalista (tempo cronológico) e a agricultura camponesa (tempo da natureza).

Sobre esse antagonismo entre tempos distintos, Gonçalves (2002, p. 44) nos assevera que "com todas as suas engrenagens o relógio é máquina de tempo e um tempo que se auto movimenta independente das temporalidades de cada ente ou cada cultura que tem seu ritmo próprio." Observamos, portanto, que as temporalidades camponesas afirmam-se diferentemente do tempo cronológico, compreendendo pela natureza o tempo de trabalhar, de plantar e de colher. Essa temporalidade é vista na diferença entre o trabalho assalariado com o dendê e o trabalho familiar com a roça.

O trabalho na roça eu acho menos penoso, porque o da roça a gente sai daqui seis horas daí dez e onze horas a gente já tá de volta, não é contado assim no relógio. E lá [Biopalma] não. Agora que lá tá bom porque é o salário né, tanto faz se você produziu ou não, você recebe o salário e na época que eu trabalhei não, a gente recebia por produção. Eles assinaram a carteira da gente como se a gente ganhasse o salário né, mas quando a gente chegava lá era outra coisa (R. T., comunidade São João Batista, Bujaru, 13 de março de 2017).

Aqui o serviço da gente é mais maneiro né, e é mais maneiro e no período de chuva o cara corre né. E lá o cara não pode parar, é roçando direto. O cara tem que fazer a produção né, tem que fazer valendo mesmo, porque quanto mais o cara produzir, mais ele ganha (D. A., comunidade Castanhalzinho, Concórdia do Pará, 19 de janeiro de 2017).

Por esses depoimentos, é possível perceber as temporalidades entre o tempo natural e o cronológico, os quais engendram territorialidades distintas no espaço agrário, tendo na materialização das práticas de trabalho a sua maior diferença.

O tempo que é gasto entre o local de morada e o local de trabalho é um movimento do modo de vida camponesa estipulado pela própria família, obedecendo a um calendário agrícola gerenciado pelo período de chuva amazônico; além de, também, levar em consideração o período festivo dos padroeiros da comunidade. O trabalho como assalariado na Biopalma constitui outra experiência de vida, que passa a ser comandada pela lógica produtiva da empresa.

Essa dualidade que se abre entre o trabalho assalariado e o trabalho familiar materializa uma relação contraditória do campesinato. Por esse prisma, observamos que do mesmo modo que a família camponesa mantém a sua autonomia produtiva e resistência a proletarização, encontra-se também subordinados e sujeitos ao capital por necessitar obter renda que permita a reprodução social da família. 
Desse modo, compreendemos que a subordinação e a sujeição camponesa ao capital, contraditoriamente, engendra mecanismos que permite a família camponesa se reproduzir na sociedade capitalista.

Dentro dessa perspectiva, os trabalhos de Martins (1980; 1996) e Oliveira (1991) são seminais para a leitura da reprodução camponesa a partir das contradições do capital que, simultaneamente, reproduz relações capitalistas de produção e a territorialização camponesa no espaço agrário.

A partir das entrevistas, observamos que o número de trabalhadores assalariados tem diminuído na Biopalma. Notoriamente, com o crescimento das palmas e a troca da força humana pelas máquinas, a oferta de trabalho na empresa diminuiu, como indica o depoimento a seguir:

\begin{abstract}
Uns três meses atrás aí a empresa tinha uns 800 funcionários, sendo que nós cheguemos aí, quando instalou tudo, por meio da terceirizada chegou a ficar com 1.600 funcionários dentro da empresa. Agora saiu muita gente e tem mais, existe mais pessoas que vem trabalhar na empresada cidade, de Bujaru e de Concórdia do que gente daqui do interior, vem um bucado de lá. O que acaba com as pessoas aqui é o horário que eles saem pra trabalhar, tinha um camarada aí do outro lado do Rio que saia 1hora da manhã pra pegar o ônibus as 6 horas aqui na estrada, aí chegava na casa dele de novo umas 7 horas da noite, aí ele dizia que durante a semana nem via os filhos dele mais, só no sábado à tarde e domingo. Tinha outro que pegava canoa pra chegar na terra firme pra depois chega aqui, um percurso de uns nove quilômetros pra chegar na beira da estrada (C. A., comunidade Arapiranga, 18 de julho de 2017).
\end{abstract}

Notamos que o contingente de mão de obra na Biopalma diminuiu em razão do processo de robotização da produção, para o qual a força humana, em algumas tarefas, não é mais necessária. Um fato importante no depoimento acima é o suposto aumento de trabalhadores da cidade em detrimento aos do campo, trabalhando na empresa produtora do dendê, fato que mostra que existem trabalhadores rurais que moram na zona urbana. Isso nos leva a pensar que o retorno dos camponeses assalariados ao trabalho da roça tem sido gradativo, ou mesmo que o assalariamento no campo tem recebido resistência dos próprios moradores do campo.

O cotidiano de trabalho na Biopalma, a partir da fala de C. A., mostra-se exaustivo para alguns trabalhadores, fazendo com que eles percam, inclusive, a convivência familiar, transformando a casa de morada apenas em dormitório, visto que passam a maior parte do dia entre os campos do dendê e o deslocamento habitual para a empresa. 
Essa precarização do trabalho pode ser vista de forma mais acintosa no período de implantação dos campos da palma do dendê, realizada por empresas terceirizadas que recrutaram muita mão de obra no processo de criação dos viveiros de mudas e, posteriormente, de plantio das palmas.

\begin{abstract}
A dificuldade com o dendê é no preparo de área. Quando a Biopalma chegou pra cá teve muita dificuldade, que teve que preparar tudo, teve que fazer o préviveiro, o viveiro. Aí o serviço se torna mais pesado. Aí depois que o dendê plantado, aí já não tem mais dificuldade não, até porque hoje o pessoal usado mais a máquina pra fazer a roçagem. $\mathrm{O}$ rebaixo por exemplo, não usam mais gente agora, usam máquina pra fazer o rebaixo, porque de primeiro usava muita gente. Agora já não existe mais essa mão de obra. Antes, as empresas grandes contratavam um terceirizado com trezentos, quatrocentos homens pra fazer o serviço todo. Aí, já que saindo do pré-viveiro, o pessoal não tinha serviço, aí colocavam pra roçar, não precisava do trator. Só que a medida que o dendê vai ficando grande, mais vai ficando limpo em baixo dele. Aí não é preciso mais fazer o rebaixo pra cortar o mato. Aí fica melhor, mais viável pra empresa colocar o trator pra rebatar o mato todo. Agora, trabalho humano só na colheita (F. S., comunidade São João Batista, Bujaru, 18 de março de 2017).
\end{abstract}

Com essa fala, compreendemos a cronologia da conformação territorial dos canteiros do dendê nos limites administrativos dos municípios de Acará, Bujaru e Concórdia do Pará. A implantação desse pólo da Biopalma foi feita pelas empresas terceirizadas, Nazaré e Muniz, que realizaram a sedimentação do que hoje são as plantações da palma africana. O início de um empreendimento desse tipo é considerado como o período mais difícil, tanto pelo tratamento quanto pela adequação do solo para as mudas da oleaginosa, como também pela falta de infraestrutura para a mobilidade para os trabalhadores.

Como exemplo do desenvolvimento da agricultura do dendê, observamos que os empreendimentos agroindustriais articulados às commodities internacionais, como o mercado global da palma de óleo, tende a terceirizar os serviços, na sua fase de implantação, só assumindo territorialmente a gerência do projeto após a fase inicial concluída. Com essa estratégia, a empresa visa diminuir os custos de produção, principalmente por ser a fase de maior contratação de pessoas, segundo os entrevistados.

Olha no começo passava muita gente aqui. No começo que a terceirizada saiu, que ela começou, empregaram muita gente. Aí depois foi enfraquecendo, enfraquecendo. Assim mesmo, ainda passa, principalmente na colheita, no rebaixo que eles roçam. Agora não, isso acabou, só trator pequeno. Aí, ela [a empresa] foi demitindo, ela comprou um bocado de trator pra quebrar a juquirá né, aí foi tirando aqueles que não querem mais, foi tirando e os outros que querem segurou (A. S., comunidade Conceição do Guajará, Bujaru, 17 de maio de 2016). 
Esse depoimento elucida que o recrutamento de trabalhadores assalariados para as plantações do dendê divide-se em dois momentos: o primeiro, de terceirizadas, que acoplou maior número de trabalhadores; e o segundo, a partir da gerência da própria empresa na contratação de pessoas.

Sobre o trabalho realizado pelas empresas terceirizadas, os depoimentos a seguir esclarecem:

Eu trabalhei na empresa, eu passei um ano e três meses lá. No tempo que entrei lá, foi nós que fizemos lá. Agora o pessoal tá de boa, só de boa. Lá fizemos roça, planta, adubação, tudo fomo nós. Monta acampamento lá do pré-viveiro, lugar pra colocar as mudas, tratemo das muda. Agora, o trabalho lá era cruel. Eu saía daqui três horas da manhã, ia de bicicleta. Aí saía de noite e chegava de noite. Nessa época não tinha ônibus, aí ia de bicicleta, pelo menos um mês. Aí depois que colocaram um pau de arara que a gente já ia nele (R. T., comunidade São João Batista, Bujaru, 13 de março de 2017).

Na terceirizada eu trabalhei um ano e seis meses. O meu serviço pra lá era assim, brocar, rebaixo. Eu saia daqui de pé pra pegar o ônibus lá no outro lado da mata, na principal deles lá, porque eles não passavam aqui. Aí tinha que acordar o que? Três horas da madrugada, o ônibus passava quatro e meia lá. Aí chegava aqui em casa, oito, nove horas da noite (D. A., comunidade Castanhalzinho, Concórdia do Pará, 19 de janeiro de 2017).

Levando em conta esses depoimentos, compreendemos a precarização do trabalho assalariado nos campos do dendê no início do projeto do pólo Concórdia, da Biopalma. Neste caso, os trabalhadores passavam a maior parte do dia deslocando-se para o trabalho dos canteiros da oleaginosa do que na própria residência, perdendo a sociabilidade com a família. Esses entrevistados ainda relatam que nesse período a família ficou sem produzir a roça.

Quando eu fui trabalhar pra lá eu abandonei a roça, fiquei sem roça. Aí quando eu saí de lá, a sorte era que eu já tinha um começo de pimenta. Aí já tirei a pimenta e investi na roça. E eu ainda consegui receber o seguro desemprego, coisa de quatro parcela. Nessa época eu não comprava farinha porque o papai fazia e dava pra nós (R. T., comunidade São João Batista, Bujaru, 13 de março de 2017).

A gente tem mandioca, tá iniciando uma pimenta, a macaxeira que a gente planta pra fazer um bolo. Temo o milho. Esse ano a gente tá com umas quatro tarefas, só com roça verde. Ficamos sem por descuido, eu trabalhava na empresa, tem um ano que sai de lá (D. A., comunidade Castanhalzinho, Concórdia do Pará, 19 de janeiro de 2017).

Apesar do afastamento da roça no período de trabalho assalariado nas plantações do dendê, percebemos que quando os camponeses retornaram à unidade doméstica, logo em seguida reativaram as atividades do trabalho na roça, refazendo cultivos e assegurando, assim, a sobrevivência familiar. 
Nesse processo, é possível reconhecer o papel das famílias extensas nas relações de divisão dos alimentos. No caso das famílias que pararam de cultivar a roça, elas recebiam a farinha de parentes próximos. Outras vezes, a esposa e os filhos ajudavam familiares e vizinhos na produção ou na colheita agrícola, assegurando parte da alimentação da família.

Diferente da estratificação social do saber-fazer da unidade camponesa, na agroindústria do dendê, o trabalho é seccionado por setores de produção, no qual várias equipes de trabalhadores possuem metas produtivas da empresa em suas mãos.

Tem o corte, a polda, o carregamento e tem a equipe da mecanização né, adubação mecanizada. E tem os ajudantes também. Tem o grupo da trapizomba que trabalha na limpeza com o trator. Tem o carregamento pra jogar os cachos pra dentro da concha e tem também a equipe da caixa e tem a equipe do meio ambiente que cuidam né, que veem o negócio da reciclagem né (C. A., comunidade Arapiranga, 18 de julho de 2017).

Segundo os entrevistados, o trabalho mais penoso é o carregamento, pois exige mais força física.

O serviço que mandava eu fazer eu fazia, mas tinha um lá que era muito pesado, que é o carreamento. Carreamento é você andar atrás do trator pegando cacho do dendê e jogando pra cima. A gente pega com o espeto porque tem muito espinho e atravessa a luva. No tempo de inverno mesmo, meu amigo, era o tempo que a gente sofria mais lá, era por dentro da lama, por dentro do lago, não tinha dessa não, tinha que acompanhar o trator. No tempo que eu tava lá, a gente carregava cacho de 30 quilos. E eles diziam que iam aumentar mais ainda. Aí o cara que não era muito acostumado fica arrebentado (D. A., comunidade Castanhalzinho, Concórdia do Pará, 19 de janeiro de 2017).

O trabalho no carreamento é estipulado pela produtividade, quanto mais cachos de dendê o trabalhador conseguir transportar para as carrocerias dos tratores, maior será o salário no final do mês. Contudo, é esse setor da empresa que precariza mais o trabalho, em razão das condições nas quais os canteiros da palma encontram-se, principalmente no período chuvoso amazônico. Outra questão importante são os pesos dos cachos de dendê que, em estágio avançado da palma, chegam a pesar entre 30 e 50 quilos, isso requer mais esforço físico dos trabalhadores, que por horas seguem com esse peso nas mãos.

A transformação dos trabalhadores em força de trabalho não é um ato mecânico que resulte de um passe de mágica. É um longo processo histórico que se tem manifestado de forma diferenciada nas diferentes realidades sociais. Além da expropriação das condições objetivas, dos meios de subsistência através, muitas vezes, de métodos violentos de acumulação primitiva [...], há a necessidade da socialização para o trabalho. Na medida em que o indivíduo é reduzido a [à] força de trabalho, é necessário prepará-lo, moldá-lo para as diferentes tarefas. Da mesma forma que um animal exige domesticação prévia para puxar um arado, todavia possua a força, a energia para isso, o trabalhador exige, para misturar-se aos demais elementos produtivos, uma domesticação 
específica: a transformação de sua vontade em vontade para o trabalho para outrem, ou seja, a dominação através da força objetiva, da vontade subjetiva (SIMONETTI, 1999, p. 130).

No universo das comunidades pesquisadas, essa domesticação do trabalho pela empresa capitalista sofre uma resistência na sua plenitude: primeiro, pelo trabalhador continuar paralelamente com a produção doméstica familiar; segundo, pela concepção da atividade no pólo do dendê não ser algo duradouro, sendo um trabalho temporário; e terceiro, pelo reconhecimento da precarização do trabalho nos campos da oleaginosa.

Eu quis sair porque no tempo que eu saí, era no tempo do piquete, tava piquetando. Aí tinha vezes que eu com um colega do Castanheiro, nó que era fraco, fazia 300 reais por mês, já pensou, no final do mês? E tinha nego, meu colega de São Judas, ele chegou a fazer 100 reais, já pensou uma coisa dessa? E quando nós saímos, olha nós passamo todo esses tempo, e nesse tempo que nós trabalhava lá, eles prometiam uma coisa, a gente trabalhava até no feriado, dia de finado, trabalhava tudinho. Aí quando eu saí, eles disseram: nós vamo fazer como a gente te tiremo. Aí eu tava aperriado porque o cara que trabalha pros outros deixa o da gente, no caso. Aí me disseram, ah é pra ti ir lá que eles já acertaram a conta. Aí eu fui pra lá, deu dois mil e pouco. Aí veio desconto em cima de desconto, quando deu foi quatrocentos reais. Aí o pessoal jogaram na justiça né, jogaram, mas eu não, de jeito nenhum (R. T., comunidade São João Batista, Bujaru, 13 de março de 2017).

Observamos nesse depoimento que o baixo retorno financeiro pode reconduzir o trabalhador camponês à unidade doméstica, não reconhecendo no assalariamento o bem-estar social almejado, principalmente pela precarização do trabalho. R. T. reitera que: "Daqui pra frente eu quero trabalhar só pra mim mesmo. Hoje a gente já tem roça, tem pimenta, açaí, cocal, tem cacau, tudo isso tem no nosso terreno. O açaí agora que tá dando, o cacau também. A pimenta a gente tá tirando já.”

Nesse exemplo familiar, ratificamos as idas e vindas do trabalho assalariado na unidade familiar camponesa, que além de ser exercido pelos homens, passou também a ser realizado por mulheres que, até 2015, trabalhavam na catação do coco de dendê caído, após a extração dos cachos da oleaginosa, e ainda hoje trabalham no refeitório da empresa.

Meus filhos trabalham aí na empresa, o meu marido trabalha no Mocajuba, ele trabalha pra lá, vem só nos finais de semana. Os meus filhos trabalham no campo, o rural palmar, trabalham contando dendê, tem dois anos já. Eu já trabalhei na empresa também, eu e o pai deles. Eu trabalhei 3 anos e o pai deles 1 ano e alguns meses. Aí quando eu saí, fiquei uns meses recebendo o seguro, enquanto eles estavam fazendo documento pra entrar na empresa. Eu saí porque não existia mais emprego pra mim, eu trabalhava no rural palmar, como acabou na época que não tinha mais, nós era 55 mulheres, aí eles tiraram a gente. Aí eles pagaram tudo direitinho. Alguns ainda jogaram na justiça, eu não joguei porque fazer uma coisa dessa né, aí meus filhos não iam ter como trabalhar. Nosso trabalho era juntar coco, quando caia do cacho, hoje eles não 
juntam mais. Eles cortam de hoje em oito em oito, ou então quando tá na safra é de cinco em cinco dias, pra que não fique aquele coco no chão e pra não ter pessoas pra juntar. Nesse caso ficou muitas mulheres, que precisam mais do que eu na verdade, que precisam trabalhar pra viver, tem uma senhora ali coitada, com um bucado de filho pequeno. Mas a gente tem terra pra trabalha, a terra da minha mãe. Só que é longe daqui, fica no município do Acará, entra lá no 10. A gente não trabalha lá, só quando é domingo, feriado, a gente vai pra lá. Lá trabalha meus sobrinho, meus irmãos, trabalham tudo na roça, no pimental. A gente já chegou a trabalhar lá, quando a gente morava no Acará, a gente morava na cidade e aí a gente vinha pro terreno da mamãe trabalhar e voltava pra cidade. Agora é meus filhos que trabalham na empresa. Eles pegam o ônibus 5 horas da manhã, eles levantam 4 e meia, aí vão pra lá pro café. Quando é 3 horas, 3 e 15 eles chegam. Lá eles param 11 e meia e voltam uma hora de novo e vão até 3 horas. Assim que era nós também, almoçava e quando era uma hora voltava pro campo (M. B., comunidade Arapiranga, 10 de julho de 2017).

Observamos que a família de M. B. tem uma rotina de trabalho fora do sítio, com os filhos trabalhando na Biopalma e o esposo como vaqueiro em uma fazenda no município de Mocajuba. A relação de trabalho nessa família foi vista como poucos exemplos, durante a pesquisa, na qual a renda da família é provida exclusivamente do trabalho assalariado. Contudo, fica claro na entrevista que a família possui um histórico de vida ligada à terra, fazendo parte de uma família extensa de forte vínculo com a roça.

Dentro da perspectiva do trabalho em instituições privadas, notamos o cerceamento que algumas famílias sofrem em relação a ações jurídicas. No caso de M. B., por mais que esteja insatisfeita com o recebimento dos direitos trabalhistas, teve receio de colocar a empresa na justiça, como outras mulheres fizeram, devido à preocupação da família ficar marcada pela ação judicial, e os filhos impedidos de serem contratados pela empresa.

O trabalho assalariado, em algumas circunstâncias, tem configurado-se como um meio de os membros mais jovens da família adquirir renda extra para a sua formação familiar particular. Vislumbrando a possibilidade de conseguir construir sua casa independe da dos pais, após o casamento, mesmo que esta seja construída no mesmo sítio, formando assim núcleos familiares extensos.

Durante a pesquisa, encontramos famílias extensas as quais desenvolvem antigas atividades de mutirões com a finalidade de ajudar algum familiar que precisa de mão de obra para a construção e o manejo da roça. Isso acontece, principalmente, entre os casais jovens, os quais o marido sai para o trabalho com a oleaginosa e a esposa contribui, com a ajuda dos outros núcleos familiares do sítio, com a manutenção das tarefas de roça, 
garantindo parte da base alimentar e da renda para a sobrevivência da família recémcriada.

Essa relação de assalariamento pré-matrimonial, ou pós-matrimonial, foi evidenciada por Woortmann (1990), a partir do processo migratório do Nordeste para outras regiões brasileiras, em busca de acumular recursos que possibilitassem iniciar a vida de casado. Desse modo, notamos que no Brasil o trabalho assalariado camponês não se constitui como fenômeno novo, mas como estratégia de sobrevivência camponesa engendrada na conformação dos territórios em resistência contra a ordem dominante da expropriação da vida no campo.

Para tornar-se homem é preciso enfrentar o mundo, mesmo entre os fortes, e retornar vencedor, o que será atestado pelo dinheiro trazido na volta. Embora a migração para "São Paulo" implique em assalariamento, ali não se é alugado, como nos canaviais, mais empregados, por mais árduas que sejam as condições de trabalho, e geralmente o são. Submetendo-se à condição de vida difíceis, gastando o mínimo para poupar o máximo, o filho retorna com algum dinheiro, com o qual irá comprar gado, ou mesmo o material necessário para a construção da casa, ou até mesmo terra (WOORTMANN, 1990, p. 37).

Os escritos de Woortmann (1990) elucidam questões que nos ajuda a pensar acerca da importância que o assalariamento adquire para a família camponesa, tornandose um víeis para a aquisição de recursos que possam ser reinvestidos para a reprodução social da unidade familiar, criando um movimento de territorialização desses camponeses via o trabalho assalariado.

Rapaz muda porque a pessoa passa a receber todo mês o seu dinheirinho certo, teve só um mês que atrasou o pagamento, mas depois eles pegaram. Já tô quatro anos lá, mas hoje em dia só de uma coisa não dá da gente viver. Do salário, o que a gente investe é na casa que a gente mora, compra as coisas pra dentro e alguma coisa por fora, como negócio de pagar conta, mas não é sempre. As vezes paga pra outra pessoa trabalhar na roça né, mas agora que trabalho meio turno dá mais tempo pra eu mexer com a roça, lá e aqui no caso. Nós tamo trabalhando agora meio turno, a gente pega meio-dia e só sai a seis horas. É por isso que tamo por aqui uma hora dessa. A empresa implantou isso né, pra fazer dois turnos pro rendimento ser maior, só pro cara descansar mais, porque só trabalho meio expediente né. Aí tem como produzir mais. O salário é o mesmo, aí vem por produção que eles pagam a gente, aí o salário aumenta um pouco. A gente ganha o salário, a produção é o tanto que o cara produz né e o vale refeição de duzentos e oitenta reais e o plano de saúde que é descontado uma porcentagem no salário. O corte é o que ganha mais né, mas as vezes é difícil cara de adaptar né. Porque na safra mesmo, no mês de setembro, a gente chega a puxar até cinco mil cachos. Aí ganha mais dinheiro quando chega na safra. A gente vai no canteiro direto tirando cachos, às vezes nem chega terminar de tão grande. Agora a colheita tá dando direto, é que nem coco, vai tirando, vai nascendo de novo, mas setembro é quando dá mais. (J. V., comunidade Nova Esperança, Concórdia do Pará, 17 de agosto de 2017). 
A fala de J. V., assalariado pela Biopalma, reafirma o comprometimento da renda provida do trabalho na empresa com a unidade doméstica camponesa. Observamos que a flexibilização da jornada de trabalho nos campos de dendê, que em algumas circunstâncias concentra-se em apenas parte do dia, possibilita que haja a concomitância, ao longo da semana, do trabalho entre a oleaginosa e o trabalho na roça.

A atividade na empresa segue a lógica da produtividade, com a garantia do salário, vale-refeição, plano de saúde e taxa do que foi produzido ao longo do mês. Essa renda tem garantido às famílias adquirirem novos utensílios domésticos, além de possibilitar o investimento na casa e no sítio.

\begin{abstract}
Ele [o esposo] agora tá trabalhando na Biopalma, tem três anos que ele tá pra lá. Aí ele mesmo não pode né, assim tá direto [na roça], mas sempre que a gente pode a gente paga né. Paga gente pra roçar, pra derrubar, pra plantar. Aí no caso, ele vai mais pra fazer limpeza né. Isso porque só do salário fica ruim, não daria pra viver com certeza, porque é um salário no caso, mas nós somos uma família de quatro pessoas. Eu, ele, minha filha e meu neto. Então não daria, mas só da roça também fica ruim. A renda da roça varia muito. Um tempo atrás tava de cem reais a saca da farinha, agora tá de 60. Então varia muito (C. M., comunidade São João Batista, Bujaru, 18 de março de 2017).
\end{abstract}

Com esse depoimento compreendemos que a articulação entre o trabalho familiar na roça e o trabalho assalariado possibilita a estabilidade almejada pela família, que está conseguindo suprir as demandas e necessidades da unidade doméstica. Evidencia-se, assim, que a combinação, ou mesmo a coexistências de racionalidades diferentes de trabalho, permite que a família fortaleça os meios de produção e alcancem a reprodução social familiar.

Apesar da estabilidade que o trabalho assalariado tem engendrado às famílias desses trabalhadores, o retorno às atividades da roça tem sido constante, principalmente pelo processo de mecanização que a empresa vem realizando. Para C, A., "agora o dendê tá mais mecanizado e as pessoas estão procurando serviços né. E aqueles que têm o seu terreno vão trabalhar pra si próprio né, voltou pra roça (comunidade Arapiranga, 18 de julho de 2017).

Observamos que o trabalho assalariado tem acontecido de forma temporária, não sendo visto como um horizonte de vida no campo. $O$ retorno para o trabalho na propriedade pode ser traduzido pelo reconhecimento da importância da autonomia do trabalho familiar camponês, não havendo mais interesse em se assalariar futuramente. Para R. T., "daqui pra frente eu quero trabalhar só pra mim mesmo”, reflexão possível após a experiência de trabalho nos canteiros do dendê. 
O trabalho de assalariado é compreendido na sujeição do trabalhador à empresa, como vislumbrado na fala a seguir:

O cara que trabalha de empregado, ele tá sujeito. E o trabalhando pra gente não, trabalha na hora que quer, sai a hora que quer. Na empresa eu acho um serviço tipo escravo porque não tem domingo, não tem nada, trabalha das seis as seis, pega seis horas e deixa seis horas. Aí eu acho que não é bom, não tem descanso, não tem dia santo, não tem o Natal, não tem nada. Então eu não acho isso certo (O. B., comunidade Castanhalzinho, Concórdia do Pará, 17 de janeiro de 2017).

Notamos nessa fala a importância dos atos simbólicos e tradições que engendram na vida camponesa um calendário agrícola pautado na vivência em comunidade. Nos dias de santo ou datas sagradas (Natal, Páscoa, Finados) e comemorativas (aniversário e casamento) não há trabalho na roça, é dia de louvor e festa na unidade doméstica. Essas relações, na concepção do trabalho assalariado, são quebradas, para o qual as formas laborais são pautadas nas metas de produção, racionalizadas pelos dias e horas demarcadas pelo relógio da empresa.

O modo de vida que o campesinato pesquisado carrega consigo tem engendrado relações familiares e comunitárias que reforçam as ações de resistência e a continuidade desses sujeitos sociais nesses territórios em constante disputa, concebendo mecanismos que reforçam a reprodução social, ao mesmo tempo que sedimenta as bases produtivas da unidade doméstica.

Desse modo, longe de uma proletarização que conforme um campo sem camponeses, esses trabalhadores têm reafirmado as suas campesinidades, assegurando a posse dos seus meios de produção, transmitindo seu modo de vida e constituindo permanentemente um processo de campesinização, ou seja, um campo com camponeses.

\section{Considerações finais}

Historicamente o assalariamento de camponeses tem colocado em questão a permanência e o lugar desses sujeitos sociais dentro da sociedade capitalista. Como vimos nesse trabalho, a partir da pesquisa em campo com famílias camponesas dos municípios de Acará, Bujaru e Concordia do Pará, observamos que no nordeste paraense o assalariamento entre as famílias camponesas sugere mais o fortalecimento da unidade doméstica do que uma suposta descampesinização. 
Tal perspectiva nos exige pensar o campesinato frente à expansão da agricultura capitalista, personificada no século XXI pelo binômio latifúndio/agronegócio, por um caminho metodológico do chão em que vive as famílias camponesas, compreendendo por dentro da unidade doméstica os mecanismos e estratégias de enfrentamento à expropriação e à subordinação total frente ao capital.

Por entre as unidades camponesas, percebemos que o assalariamento tornou-se um suplemento à renda adquirida da terra. Com a desvalorização comercial dos produtos vindos da roça, o trabalho assalariado complementa a renda familiar, composição essa que tem garantindo a reprodução social necessária para manterem-se a viver no campo, constituindo espaços de vida e de trabalho a partir da lógica familiar camponesa, mesmo que, contraditoriamente, encontram-se subordinados e sujeitos ao capital.

A expansão do dendê pelo nordeste paraense não tem, desse modo, constituído um campo sem camponeses, mas tem possibilitado a conformação de um espaço agrário mais complexo, onde as relações de trabalho são conduzidas não para uma terminalidade, mas para a superação das resiliências que o campesinato experimenta ao longo de sua trajetória social.

A pesquisa nos revelou que são poucos os camponeses que se assalariam e permanecem nos campos da empresa da oleaginosa, havendo sempre um retorno ao tempo de plantar e colher próprio da agricultura de roças amazônicas, obedecendo aos regimes de chuva e safras que permitem a reprodução social desses camponeses.

Contudo, não desconsideramos a importância que o trabalho assalariado engendra na unidade doméstica camponesa, mas a partir dos relatos em campo, observamos que a labuta na temporalidade da empresa é desencadeada pela precarização do trabalho, principalmente no período de instalação dos viveiros e canteiros do dendê. Esse trabalho assalariado nos campos de dendê demarcar a subordinação e sujeição camponesa ao capital, ao passo que vendem a força de trabalho para suprir a necessidade familiar.

O retorno dos camponeses assalariados ao trato com a roça tem sido demonstrado em nossa pesquisa, sobretudo por meio da robotização de manejo nos varadouros da oleaginosa, o que tem diminuído os postos de trabalho na empresa. A consciência do trabalho precário também tem sido um indicativo do retorno ao trabalho 
na roça, compreendendo, por esses camponeses, uma melhor qualidade de vida na realização das atividades de trabalho entre os familiares.

Retornar à roça, além de estar garantindo a esses trabalhadores a sobrevivência de seus familiares, tem reforçado e valorizado o olhar sobre autonomia da vida e do trabalho na unidade doméstica camponesa.

\section{Nota}

\footnotetext{
${ }^{1}$ Apesar de os camponeses e camponesas terem permitido as gravações das entrevistas e suas respectivas transcrições para a redação deste trabalho, optamos por trocar os nomes verdadeiros por letras iniciais de nomes fictícios dos depoentes, preservando, assim, o nome dessas famílias camponesas.

${ }^{2} \mathrm{O}$ número de unidades domésticas pesquisadas em algumas comunidades alcançou o número total de famílias. Em outras comunidades, devido o grande número de residências, não foi possível acompanhar todas as unidades, realizando a análise a partir de uma amostragem mínima de 15\% do total de famílias.

${ }^{3}$ Dados cedidos pelos agentes comunitários de saúde.
}

\section{Referências}

BOMBARDI, L. M. O Bairro Reforma Agrária e o processo de territorialização camponesa. São Paulo: Annablume, 2004.

CONCEIÇÃO, A. L. Produção do espaço e conflitos territoriais: expropriação da terra e exploração da natureza. In.: SUERTEGARAY, D. M. A. (ORGs). Geografia e conjuntura brasileira. $1^{a}$ ed. Rio de Janeiro: Consequência Editora, 2017, p. 13-34.

GONÇALVES, C. W. P. O latifúndio genético e a r-existência indígeno-camponesa. Geographia: Niterói/RJ, UFF/EGG, 2002, p. 39-60.

IANNI, O. Relações de produção e proletariado rural. In.: SZMRECSÁNYI, T \& QUEDA, O. (ORGs). Vida rural e mudança social: leituras básicas de sociologia rural. $3^{\text {a }}$ ed. São Paulo: Ed. Nacional, 1979.

KAUTSKY, K. A questão agrária. Tradução de Otto Erich Walter Maas - São Paulo: Nova Cultura, 1986.

LÊNNIN, V. O Desenvolvimento do capitalismo na Rússia. São Paulo: Nova Cultural, 1985.

LUXEMBURGO, R. A acumulação do capital. Rio de Janeiro: Zahar Editores, 1979.

MARTINS, J. S. Expropriação e violência: a questão política no campo. São Paulo: Editora Hucitec, 1980.

MARTINS, J. S. O cativeiro da terra. 6ª edição. São Paulo: Editora Hucitec, 1996. 
MONTEIRO, M. A. De camponês a assalariado agrícola: impactos da expansão de e dendê na Amazônia. In: BAHIA, M. C. \& MARTINS, D. (ORGs). Estado, sistemas produtivos e populações tradicionais. Belém: NAEA, 2014, p. 221-242.

NAHUM, J. S. \& BASTOS, C. S. Do sítio camponês ao lote de dendê: transformações do espaço rural na Amazônia paraense no século XXI. Revista NERA (UNESP), v. 37, 2017, p. 54-76.

OLIVEIRA, A. U. A agricultura camponesa no Brasil. São Paulo: Contexto, 1991.

SANTOS, J. V. T. Colonos do vinho. São Paulo: Editora Hucitec, 1984.

SIMONETTI, M. C. L. A longa caminhada: a (re)construção do território camponês em Promissão. Universidade de São Paulo, Programa de Pós-graduação em Geografia Humana, São Paulo-SP, 1999. (Tese de doutorado).

VERGÉS, A. B. Os novos camponeses: uma leitura a partir do México profundo. Tradução: Maria Angélica Pandolf. São Paulo: Cultura Acadêmica; Cátedra Unesco de Educação do Campo e Desenvolvimento Rural, 2011.

WOORTMANN, K. Migração, Família e Campesinato. Revista Brasileira de Estudos de População, n.1, p. 35-53, 1990. 